\title{
The Footwear Online Shopping Experience: Word of Mouse Tell How e-Service Quality Enhance Customer Satisfaction and Loyalty
}

\author{
Nanis Susanti, Surachman, Djumilah Hadiwidjojo, Fatchur Rohman \\ Department of Management, Faculty of Economics \& Business, Brawijaya University, East Java, Indonesia
}

\begin{abstract}
This study reveals and illustrates how online store customer's perspective about e-Service Quality, e-Satisfaction and e-Loyalty, as expressed in online customer reviews. The discussion associated with the online shopping phenomenon for the search good and experience good category in apparel product lines - especially shoes. Using data from Zappos.com's customer reviews, interpretive analysis which focused on customer evaluations of the service quality, and how the customer connect it to satisfaction and loyalty. Data with review depth of more than 15 lines within 18 months period (January 2011 - March 2012) was used to reveal the customer's perspective of the studied dimensions.
\end{abstract}

Keywords - Customer Satisfaction, Customer Loyalty, Online Shopping, Service Quality, Word of Mouse.

\section{Introduction}

Depiction of the online customer behavior have been emphasized by Jonathan Carson that the Internet is no longer a niche technology - it is mass media and an utterly integral part of modern life. ${ }^{1}$ This phenomenon is shown by many consumers are using the Internet to search for and purchase products. For many consumers in Southeast Asia, digital media is ingrained in their everyday lives, and in some countries internet usage is even surpassing time spent on traditional media such as television or print. ${ }^{2}$ Mentioned that Singapore has the highest Internet penetration at 67 percent, whilst Indonesia trails the region with just 21 percent penetration. However in the same period the total population in Singapore was recorded at 5 million people ${ }^{3}$ and Indonesia reached 260 million. ${ }^{4}$ Hence the researcher conclude that the influence of the Internet is much more widespread in Indonesia. This broad Internet influence is potentially growth the online business opportunities in this country. Forward research is needed to improve understanding and developing the concept of service quality in online business.

Some study found that there are many Internet user still doubts to conduct transactions via Web site. This is mainly attributed to privacy and trustworthiness ${ }^{5}$ in the virtual world. Technology Readiness and Service Quality has also conneted to online shopping behavior. ${ }^{6}$ Several research linking the three-dimensions of eQuality (system quality, information quality and service quality), ${ }^{7,8}$ satisfaction and loyalty. Recent surveys of consumers indicate that e-Service Quality is generally low. ${ }^{9}$ Therefore, empathy is important in customer's perception of the e-Service Quality. ${ }^{10}$ In the online securities brokerage service found more customer dissatisfaction. ${ }^{11}$ Conversely, Amazon.com successfully in globally online book store service and Zappos.com thrive achieving online shoes market in the U.S., with $60 \%$ repeat purchase rate and many customers doing voluntary promotions - Word of Mouth ${ }^{12}$. It is known that shoe is product which customer considering various process to make purchasing decision. This involves of many factors (searching) including material, style, color, model, and price. Furthermore, the process of trying or experiencing - physically (sizing and fitting). Because of that, it is rather impossible to imagine that footwear products could sell online successfully. From the barriers and successful profile of this online business, it is necessary conducting research to improve understanding and developing the concept of online services quality. This study was to explore the service quality dimensions which could satisfy and cultivate online store customer loyalty.

Online promotion activities from one to many other consumer (C2C) is known as Word of Mouse or electronic Word of Mouth (e-WOM). Word of Mouse includes attribute rating or customer reviews on the product quality, service quality and online shopping satisfaction. A lot of information from the customer is a valuable database of customer feedback. Several studies utilizing this database, including to investigate why online customers dissatisfied ${ }^{13}$ with the frequent-flier program in the airline industry, particularly the negative Word of Mouse in the online feedback forum. Other investigated the importance of listening (listen in) conversations in social media, ${ }^{14}$ such as: discussion forums, micro-blogs, blogs, social networks, mainstream news, wiki, video and review sites to conclude brand sentiment. Through the review and online expression of Word of Mouse, this research explores how customers evaluate service quality dimensions of shoes online store. This study analyzed how customers connect service quality to satisfaction and loyalty.

\section{Objective of the Study}

This study aims to exploration and explanation how online customer perspective on e-Service Quality, e-Satisfaction and e-Loyalty. Online customer reviews are the one Word of Mouth platform (e-WOM). 
Customer review is the expression of the customer experiences in online shopping were posted into the Web site. Exploration conducted on the text review to find what service quality that customers appreciated. The next is explained how the relationships between service quality, satisfaction and loyalty. Data downloaded from Zappos.com - American online shoe store.

\subsection{Online shopping}

\section{Review Literature}

More than 85 percent of the world's online population have used the Internet to make purchases, ${ }^{15}$ increased by 40 percent from two years earlier, and more than half of Internet users are regular online shoppers, who make purchases online at least once a month. With the increasing penetration of the Internet, the growth of online business is wider and the community is getting ready to shop online. Various products marketed through Internet, as well as cooperation between businesses (B2B). Some companies which market underwear products (lingerie fashion) cooperate and join to a network Web site. Web-weaving ${ }^{16}$ is a strategic "e-portfolio management" approach. This approach can identify a multi-niche opportunities for e-retail, which spread risk, maximizes revenue streams, utilizes knowledge economies/synergies across multiple-web sites, promotes customer added value and offers potential for competitive adventage and sustainability for the smaller-sized eretail.

Shoes is a product that has a mix between a search and experience good, because the purchase of shoes (offline) will be determined by the customer choices consider to both the searching characteristics, such as: models, materials, colors, and details and assess the experience characteristics with direct experience or try the shoes comfort to foot posture or structure. According to Huang at al. (2009): "The dominant attributes of a search good can be evaluated and compared easily, and in an objective manner, ..., while the dominant attributes of an experience goods are evaluated or compared more subjectively and with more difficultly". ${ }^{17}$ Referring to Nelson (1970, 1974): "Search goods are those for which consumers have the ability to obtain information on product quality prior to purchase, while experience goods are products that require sampling or purchase in order to evaluate product quality" ${ }^{18}$ Digital camera, cell phone and laser printer are example of search good, ${ }^{19}$ clothes style, color of the car is an example of the search characteristic. ${ }^{20}$ Music CD, MP3 player, video game are example of experience goods, ${ }^{21}$ the taste of a grocery product would be typical example of an experience characteristic. ${ }^{22}$ This study explores the various dimensions and attributes which used by online shoes stores customers.

In the offline context, various characteristics of retail environment (product assortment, value of merchandise, salesperson service, after sale service, facilities, atmosphere and store location) influence consumers' emotional responses in the shopping environment, and in turn influence consumers' store attitudes. ${ }^{23}$ Some exploratory studies focusing on online stores have done. Ordering time, quality, delivery time and substitute are the most important attributes for online grocery shopper ${ }^{24}$ Fulfillment attributes dominate eSatisfaction and repurchase intention judgments. ${ }^{25}$

Comparing between context, there are differences online and offline shopping motivation. Services are more likely to be associated with the online shopping mode, whereas more tangible products are likely to be associated with bricks and mortar stores. ${ }^{26}$ Contrary, concluded that in (offline) retailing services, customer satisfaction would be dependent on the relationships retailers build with their customers through interactions. ${ }^{27}$ In the online shopping context, the interaction between personnel and costumer is an obstacle course, while the customers needed a mechanism to met information. There states that online retailers need to provide more information (e.g. FAQs) - Frequently Ask Question and make browsing easier to help customers have satisfactory shopping experience. ${ }^{28}$ Attentiveness had significant impacts on both customers' perceived overall service quality and their satisfaction, ${ }^{29}$ so that online retailers should do their best to provide a personal and individual service to their customers, even though they use impersonal media Web sites, as their primary marketing and distribution channels.

Some studies focusing on fashion product have been carried out. One conclude that the store environment and store design particularly is an important factor in determining the personality fashion store. design. ${ }^{30}$ Another factor are: corporate social responsibility, reputation, service level, the salespeople, the merchandise sold, price/quality perceptions and the consumer base determine perceptions of "genuineness", "solidity", "sophistication", "enthusiasm" and "unpleasantness". In the online context, the fashion shopper in Korea are classified into: ${ }^{31}$ (1) fashion/brand shopper presented the highest levels of overall satisfaction and intention to purchase fashion goods online (2) fashion follower showed the opposite.

\subsection{Service Quality}

Service quality is a prerequisite for customer satisfaction and will determine customer loyalty. Satisfied customers will show their loyalty by doing repeat purchases and word of mouth voluntarily. From the study of several literatures, some study found the differences of the service quality, customer satisfaction and loyalty 
discourse in online and offline shopping context. The constancy of theoretical concepts in the offline shopping context is adopted and still adapted to the online shopping context. Five dimensions ${ }^{32}$ of service quality in offline contexts have developed in 1994 and have been widely accepted: (1) Tangible is the appearance or availability of facilities such as buildings, spatial and property (2) Reliability concerns the ability to deliver the promised services with the same quality (consistently) at any time so that the customer can set the trust (3) Responsiveness is the willingness and readiness of employees in providing services and solutions (4) Assurance related to the company's ability and employees behavior in instilling a sense of trust and confidence to its customers (5) Empathy is special attention given to each individual customer, understand customer needs and wants.

In the online shopping context has conducted a review and synthesis of the literature on the service quality delivery via Web site and generate conceptualizations ${ }^{33}$ of four core e-SERVQUAL: (1) the efficiency related to the ease of customers to enter the Website, find the products and related information, logout from Website easily (2) reliability, associated with the works of technical functions in the site (3) fulfillment is associated with the accuracy of services as promised, the product is ready in stock, and delivery of products within the promised time (4) privacy, including warranties that data related to shopping transactions do not fall to the other party and the security of credit card information. In addition to the four core dimensions, also developed three recovery e-SERVQUAL: (1) responsiveness is a measure of the online retailers' ability to provide appropriate information for customers who have problems, and the availability of mechanisms of returns. (2) compensation includes the money-back policies and the costs of handling and return. (3) contact, availability of customers facilities to talk directly online or over the phone with customer service.

Those seven dimensions are still being developed in several studies. By conducted a review and synthesis of 25 studies over the period 1996-2008 generate a set of eight scales measuring e-Service Quality: ${ }^{34}$ (1) Website design is related to Website framework which fulfill the attributes that support customers to make a purchase online with ease, through a good navigation and information functions (2) personalization is associated with policies to meet the customer's demands and personal needs which related to payment and shipping ways. (3) empathy is related to the availability of individualized attention, empathy, courtesy to customers in the process of contact (phone, email), settlement of complaints on a friendship manner. Furthermore, the five dimensions essentially the same as those known before (4) reliability (5) responsiveness (6) security (with privacy), (7) fulfillment (8) information (same with efficiency).

\subsection{Satisfaction and Loyalty}

Experience required by the customer to assess whether the quality perception is manifested through delivery of service quality perceived. In order to run a superior service quality, the Web company's manager, first must understand how costumers perceived and evaluate online customer service. ${ }^{35}$ The study conducted a test of the concept has been developed resulting two main dimensions ${ }^{36}$ four dimensions of service quality E-SQUAL: efficiency, system availability, fulfillment, privacy and three dimensions problem handling service ERecs-QUAL: responsiveness, compensation and contact. Four dimensions of measurement scale of customer Perceived Value: 1) price 2) overall convenience of using site 3) the extent the site gives a feeling being in control, and 4) overall value from the site related money and effort. Four dimensions of measurement of Loyalty Intention: 1) positive WOM 2) recommendations to someone who seeks advice 3) encourage friends and others to do busineess with site 4) consider site to be the first choice for future 5) do more business with site

One successful strategy to satisfy and retain customers is by offering superior service quality and correlates it with customer satisfaction and loyalty. ${ }^{37}$ There is an empirical relationship between the brand attributes and the corporate brand image (the emotional value) in turn influences the customer's responses 9loyalty). ${ }^{38}$ Customer satisfaction plays a very important role in the competitive environment of e-commerce, because of its impact on customer loyalty. ${ }^{39}$

\subsection{Word of Mouth}

Word of mouth is the voluntarily customers activity to share their experiences about the quality of services and products. The Internet has changed the way consumer communicate. ${ }^{40}$ Because of the popularization of the Internet and fast access to information, the number of people surfing the Internet increases every year, and people gradually rely on the Internet to aqcuire information. ${ }^{41}$ Increasingly, consumers use the Internet as a vehicle for pre-purchase information gathering. ${ }^{42}$ Study to the effect of Internet book reviews on reader borrowing intention has conclude that numbers of references and content of internet book reviews play an important role in borrowing book intention. ${ }^{43}$ Through the Internet, customers can express their emotions both verbally and non-verbally on some Web-based review platforms ${ }^{44}$ such as through forum discussion, blogs and others. ${ }^{45}$ Popularity of virtual community is increasing. ${ }^{46}$ Online feedback mechanisms are best known as a technology for building trust and fostering cooperation in online marketpalce, such as eBay, are poised to have a much wider impact on organizations. ${ }^{47}$ Some even develop product modifications and innovation, which they 
post online and share with other community members. ${ }^{48}$ Through Web-based consumer opinion platforms (e.g., epinion.com), the Internet enables customers to share their opinions on, and experiences with, goods and services with a multitude of other consumers. ${ }^{49}$ A study verified that consumers use Internet message boards in order to exchange information and advice about cosmetic surgery. ${ }^{50}$ MySpace.com has changed the way consumers find and share information on fashion apparel. Consumers control the marketing of fashion ${ }^{51}$ reflected by four categories of the most popular discussions those are personal style, brands and designers, tips and advice, and retailers. Reviews on Amazon Web site is considered as one of the most successful features. ${ }^{52}$ Referring to Schweidel, et al, $(2011)^{53}$ the product review communities allow customers to share their opinions and emotions (brand sentiment) related to the purchase or use product. For producers, an understanding of online customer interaction through a simple rating system could figured out how to satisfy their customers, and for social scientists will provide insight into how emotional communication happens online.

Satisfaction is the outcome of an affective process that for the movie audience, pleasure and arousal will affect satisfaction, word of mouth communication, and potential to foster WOM. ${ }^{54}$ Pleasure and arousal have a significant effect on WOM. ${ }^{55}$ Trust is judged to be as important as satisfaction to drive of WOM, showed that strong emotional responses in the trust encourages people to make positive comments about their service providers. ${ }^{56}$ WOM have high reach, are generally cheaper than traditional advertising and more trustworthy. However, companies have less control over WOM strategies, since the way in which communication spreads among consumers is more random than in advertising. ${ }^{57}$ Word of Mouth is a verbal informal communication occuring in person, by telephone, email, mailing list, or any other communication method regarding a service or a good. ${ }^{58}$ Seven characteristics of e-WOM sources are posted reviews, discussion forums, mailbags, electronic mailing lists, personal e-mail, chat rooms, instant messaging. Consumer use WOM to facilitate the decision process (i.e., provide specific input to a decision) and to help reduce dissonance related a decision (i.e., postdecision support). ${ }^{59}$ Popular online bookstores such as Amazon (www.amazon.com) in the United States and Books.com (www.books.com.tw) in Taiwan, achieve success from the book promotion by providing a facility of online book reviews. ${ }^{60}$ When reading an online review, if a reader senses resonance with the reviewer and can imagine him - or herself in the situation described in the review, he or she may perceive the review as more credible and trustworthy and hence more persuasive. ${ }^{61}$ Some conclution cited: ${ }^{62}$ WOM communication plays a more important role than market-generated information, such as advertising or personal selling, in influencing consumer behavior (Katz and Lazarsfeld 1955), because consumers perceive WOM as more trustworthy, which may lead to greater persuasiveness (Wilson and Sherrell 1993). With WOM, cues such as the relationship with the information seekers or biological or social commonality between information seeker and the source can be used to develop a sense of trustworthiness (Gilly et al. 1998; Rogers 1983).

In the view of knowledge management, found differences between the company and customers. Customers place a high value on the facets which facilitate interaction, communication with other consumers and $\mathrm{C} 2 \mathrm{C}$ knowledge exchange. Companies placed more value on the marketing facility ${ }^{63}$ The importance of eWOM for customers has been studied and found four core categories of dialogue or a special conversations (unique) which consisted of valuable information for the development of services, such as: information request, usage experience, business practice issues, and comments pertaining to the new product launches. ${ }^{64}$

Some of customer reviews study showed that the presence of the online customer opinions platform practically and theoretically have earned a position in shaping the behavior of online customers. The results of a survey identify ${ }^{65}$ that $81 \%$ of online shoppers in the holiday season read online customer reviews. Customer reviews are important tools for costumers to search information online, $71 \%$ agreed that consumer reviews make them more comfortable because they are buying the right product. Online customer reviews become a cognitive sorce of information which is very useful for both potential customers and product manufacturer ${ }^{66}$ Moreofer explained that customer use the information from the online customer reviews to support their decision in determining the purchase of the product. In the perspective of the manufacturer, an understanding of customer preferences is valuable information and knowledge for product development, marketing and consumer relationship management. Consumer review can serve as a new element in the marketing communications mix and work as free "sales assistants" to help consumers identify products that best match their idio syncratic usage conditions. ${ }^{67}$ Customer reviews are the source of online recommendations which could influence the online products choices, ${ }^{68}$ contains about consumer motivation to buy and what they do with those purchases, ${ }^{69}$ a new type of word-of-mouth information, emerged as a phenomenon that is playing an increasingly important role in consumers' purchase decisions. ${ }^{70}$

\section{Data and Methodology}

Customer review text data period of 18 months (January 2011 - March 2012) were collected from the online shoes store Web site, zappos.com. 1057 texts were collected, converted in the Microsoft Word (Times New Roman font 12), classification based on interval number of lines in each text. From those data already collected four customer review text classifications: 1-5 (680), 6-10 (276), 11-15 (64), > 15 (37). Data worthy to 
analyzed are text with more than 15 lines, it is to get the reviews depth and completeness. The reviews' depth and completeness is needed to reveals and explains how customers evaluate and connecting dimensions studied. Thirty seven customer reviews text imported into MAXQDA 10 software and do the coding process. Content analysis was used to determine the suitability of the themes found with defined concept dimension. Software can also generate an integrated picture of the connectedness pattern of within text and between text themes. This facilitates the process of data analysis both individually and in total.

\section{Finding and Discussion}

Table 1 is the exploration result of the 37 customer reviews, found 10 key dimensions (parent code) of customers' shopping experience on footwear online store zappos.com. Dimensions specified on the coding initial step are: ES-QUAL, E-RecS-QUAL, Perceived value, and Loyalty, but in the process researcher determined dimensions which are perfectly suited to the expression that appears, namely: emotional satisfaction, trust, Xtra-S -QUAL, Product and WOM influence. Emotional satisfaction is an expression of satisfaction which expressed verbally through the choice of words in a expressive sentences or non-verbally by using the capitalization of a word or phrase or expression using punctuation usually followed by compliment. Trust is a customer expression which recognizes a reputation for online store. This statement looks very connected with emotional satisfaction. Researchers set Xtra-S-QUAL attribute to represent the extraordinary of service quality perceived by customer as a surprise or excitement. Product is an attribute that was also received appreciation from customers, while the WOM influence is the claim that they are shopping at online stores concerned of recommendations from friends or relatives.

10 dimensions detailed in 23 attributes (sub-code) with a total of 206 codes (frequency). Percentages indicate the relative importance between dimensions and relative importance attributes within the dimension. Based on percentage rank, obtained a description as follows:

1. There are emotional satisfaction and loyalty at $19.42 \%$ each.

2. E-RecS-QUAL (12.62\%) as important as E-S-QUAL (10.68\%)

3. Trust $(12.62 \%)$

4. Xtra-S-QUAL (7.28\%) and empathy $(6.31 \%)$

5. Perceived VALUE, Product and WOM influence are $5.34 \%, 4.37 \%$ dan $1.94 \%$ respectively.

These findings explain the relationship between dimensions in online stores. Service quality (especially the fulfillment by $72.73 \%$ ) and service handling problems (responsive $50 \%$ and contact $42.31 \%$ ) are the main factors which linked to the customer's emotional satisfaction. Extraordinary experience raises a pleasant surprise aspect of the customer, as well as the empathy attitude of customer service when interacting with customers over the phone. Xtra-S-QUAL and Empathy (friendly dominates with 61.54\%) was able to increase the emotional satisfaction of customers. Emotional component in customer satisfaction further establish the trust (the recognition of the online store's reputation 76.92\%) and true loyalty (first site choice $40 \%$ and do more business $30 \%)$.

Important finding in this study is the uncovering of the emotional satisfaction of online customers shopping. Here is an overview of the importance of maintaining emotional satisfaction, where superior service quality can be felt through the dimensions as below (eg. as expressed from several customer reviews):

1. Fulfillment

"I just feel like I am running another quick errand around the house rather than shopping". "Ordering and shipping is a piece of cake". "Shipping is incredibly fast". "I just ordered the bag yesterday and it was at my doorstep today".

2. Contact

"I have been on a 'high' for the rest of the day after my phone call with one of your reps". "Searching for that special gift for my granddaughter by phone". "I received the email I'd hoped for". "Contacting your customer support has been always quick and easy".

3. Responsive

"I can return it without any hassle". "She will call me back when she hears that they are in". "Free return shipping". "My refund was issued in the timeliest manner". "New shoes were sent to my temporer address".

4. Xtra-S-QUAL

"It wasn't an email, but a real card". "She sent me a bouquet of flower". "In-home shoe fitting". "They sent me a get well card an on top of that she sent me a box of Mrs. Field's cookies". "Cookies and anote from CS Rep".

5. Friendly

"Friendly, caring, talkative". "Your guys are all incredibly empathetic, kind, thoughful". "A lovely young lady in the call center was so kind".

These are the expressions of emotional satisfaction related to trust and loyalty: 
1. Reputation

"What internet shopping could - and should - be". "Amazing organization". "Honestly, the world could take nice lessons from everyone at your company". "Very unusual and loving company". "Constantly reference your customer service as a benchmark for our company".

2. First site choise

"I check with you first before I buy anytihing". "I will not be shoping anywhere else except here". "You have made me a customer forever". "I have made a commitment to your guys which I will continue to honor".

3. Do more business

"A very happy customer that will be ordering again soon". "I will most definitely be shopping with your company again". "What next on my list? A pair of Sperry boat shoes"

Next are the ways the customer express their emotional satisfaction:

1. Verbal

"Buying from you was a breath of fresh air". "I had the extreme pleasure of encountering today". "I wanted to make sure you know just how amazing I think you are". "Thank you. I remain truly impressed and pleased with my experience". I will definitely do my Christmas shopping with you next year".

2. Non verbal

Some words or phrases are found using capital letters and punctuation: LOVED, WOW, THE BEST!!!, VERY IMPRESSED, OMG, ROCK! OUT FOR DELIVERY! THANK YOU!

Finally this is the picture how customer linked their emotional satisfaction with trus and loyalty: "Thank you more than I have words to express for not only assisting me with my shoes and boots, but thank you more for the cards and OMG, bouquet of 'get well' and 'good luck' with my surgery today, and the next 2 surgeries scheduled next week" (this is the customer expression about the extraordinary experience they have with online shoe store). (For this reason he continues express): "OMG you blow me away!!!! I am a disability retired Police Officer, badly injured near the end of my 21 year career and you guys had all been like friends to me. The Police Dept. should use the hiring and psychological screening process used by ...." (this is customer recognition to the online store reputation - trust). Then (He thank for had emotional satisfaction): "Again- thank you big time for being the uniquely professional and kind human beings you each are. Thank you for the cards and incredible flowers. You have all touched my heart". (And stated his loyalty): "obviously-a loyal VIP customer! Sincerely and from my heart"

Table 2 provides a justification about relation between emotional satisfaction with the dimensions. Emotional satisfaction perceived from service quality (24) and problem handling support (34). Empathy (16) and X-Qual (15) increases emotional satisfaction. Emotional satisfaction generate trust (25) and loyalty (48).

\section{Conclusion}

Online customer reviews (testimonials) could uncover and describe how the perspective of online shop customers on E-Service Quality, E-Satisfaction and e-Loyalty. This perspective is become crucial to apparel product lines which involving 2 process of purchase decision-making process, searching and experience. In the brick and mortar, this process can be realized because it is supported by tangible component in the offline stores, but not in the online store. This study specifically explores footwear online shopping experience, but this study's findings also contribute to how to develop the concept of e-Service Quality, E-Satisfaction and e-Loyalty on the gneral online store.

Order fulfillment is dominant service quality attribute to create online customer satisfaction, in line with the findings of Wilson-Jeaneime and Reinolds (2006); Dholakia and Zhao (2010). Contact, responsive and friendly are the keys of customer satisfaction when facing and gain problem solving. This is in line with the statement of $\mathrm{Li}$ and Suomi (2009) which stated that empathy is a very important dimension in customer perception about the service quality. Similarly with Kim and Stoel (2005) and Jun and Kim (2003) conclude that attentiveness is an important dimension of service quality, so online retailers should do their best to provide personal service to their customers, even though they use impersonal media such as Web site, as the main distribution channels and marketing. Emotional satisfaction established trust and further determine customer loyalty. In the offline context, it is concluded that the characteristics of retail stores environment (product choise, value, service people, post service and store facility) affect emotional responses on the shopping environment, and these emotions in turn influence consumer attitudes towards store (Yoo et al., 1998). Khare, A., Ceeba and Reena Rai Parveen (2010) concluded that in the offline retail service, customer satisfaction depends on the interaction with the customer service people. In the context of online shopping, personnel interaction surely become an obstacle, while customers need the mechanisms to meet their need of information. Researchers determined that in the online context, in the absence of face to face then contact, responsiveness and empathy are very crucial to determine emotional satisfaction and affect the customer's attitude towards online stores. This is in line with the findings of the motivational differences between online and offline 
shopping. Rajamma, Audhesh K. Paswan and Gopala Ganesh (2007) concluded that service more connected with the context of online shopping while tangible product more connected to the context of offline stores. Then the researchers determined that superior service quality determines the emotional satisfaction of customers. One of successful strategies to satisfy and retain customers is by offering superior service quality, and connected it with customer satisfaction and loyalty (Swaid and Wigand, 2007). There is an empirical relationship between corporate image and brand attribute (emotional value) and in turn determine the response of customers (loyalty) (Da Silva and Alwi 2006). Customer satisfaction plays a very important role in the competitive environment of e-commerce because of its impact on customer loyalty (Chung and Shin, 2010). Superior quality service that creates consumer delight is the finding in this study. Extraordinary experienced create a sensation that could not be ignored in creating emotional satisfaction. Furthermore, the emotional satisfaction is crucial in establishing customer confidence online store's reputation. Emotional satisfaction and trust are crucial to determine real customer loyalty on online store.

TABLE - 1

CODE RELATION MATRIX

\begin{tabular}{|c|c|c|c|c|c|c|}
\hline \multirow[b]{2}{*}{ Parent Code } & \multicolumn{2}{|c|}{$\begin{array}{c}\text { Parent Code } \\
\text { Statistic }\end{array}$} & \multirow[b]{2}{*}{ Sub Code } & \multicolumn{3}{|c|}{ Sub Code Statistic } \\
\hline & Frequency & $\%$ & & Freg. & $\begin{array}{c}\% \\
\text { Total }\end{array}$ & $\%$ Parent \\
\hline \multirow{4}{*}{ E-S-QUAL } & 22 & 10,68 & Efficiency & 6 & 2,91 & 27,27 \\
\hline & & & System Availability & 0 & 0,00 & 0,00 \\
\hline & & & Fulfillment & 16 & 7,77 & 72,73 \\
\hline & & & Privacy & 0 & 0,00 & 0,00 \\
\hline \multirow[t]{3}{*}{ E-RecS-QUAL } & 26 & 12,62 & Responsive & 13 & 6,31 & 50,00 \\
\hline & & & Compensation & 2 & 0,97 & 7,69 \\
\hline & & & Contact & 11 & 5,34 & 42,31 \\
\hline \multirow[t]{3}{*}{ Perceived VALUE } & 11 & 5,34 & Price & 9 & 4,37 & 81,82 \\
\hline & & & Overall Value & 2 & 0,97 & 18,18 \\
\hline & & & $\begin{array}{l}\text { Perceived } \\
\text { Convenience }\end{array}$ & 0 & 0,00 & 0,00 \\
\hline \multirow[t]{5}{*}{ LOYALTY } & 40 & 19,42 & Positive WOM & 7 & 3,40 & 17,50 \\
\hline & & & $\begin{array}{l}\text { Recomendation to } \\
\text { some one ask }\end{array}$ & 0 & 0,00 & 0,00 \\
\hline & & & Recomendation & 5 & 2,43 & 12,50 \\
\hline & & & First site choice & 16 & 7,77 & 40,00 \\
\hline & & & Do more business & 12 & 5,82 & 30,00 \\
\hline \multirow[t]{2}{*}{ EMOTIONAL } & 40 & 19,42 & Verbal & 21 & 10,19 & 52,50 \\
\hline & & & Non Verbal & 19 & 9,22 & 47,50 \\
\hline \multirow[t]{3}{*}{ EMPHATY } & 13 & 6,31 & Personal & 2 & 0,97 & 15,38 \\
\hline & & & Friendly & 8 & 3,88 & 61,54 \\
\hline & & & Courteous & 3 & 1,46 & 23,08 \\
\hline \multirow[t]{4}{*}{ TRUST } & 26 & 12,62 & Human-Machine & 0 & 0,00 & 0,00 \\
\hline & & & Risk & 1 & 0,49 & 3,85 \\
\hline & & & Reputation & 20 & 9,71 & 76,92 \\
\hline & & & Experience & 5 & 2,43 & 19,23 \\
\hline Xtra-S-QUAL & 15 & 7,28 & & 15 & 7,28 & \\
\hline \multirow[t]{2}{*}{ Product } & 9 & 4,37 & Product quality & 7 & 3,40 & 29,17 \\
\hline & & & Product view & 2 & 0,97 & 8,33 \\
\hline WOM influence & 4 & 1,94 & & 4 & 1,94 & \\
\hline Total & 206 & 100 & & 206 & 100 & \\
\hline
\end{tabular}

TABLE - 2

CODE RELATION MATRIX

\begin{tabular}{|l|r|r|r|r|r|r|r|r|}
\hline & \multicolumn{1}{|c|}{ S-Qual } & \multicolumn{1}{l}{ R-Qual } & \multicolumn{1}{l|}{ P-Value } & \multicolumn{1}{l}{ Loyalty } & Emotion & Empathy & \multicolumn{1}{l|}{ Trust } & \multicolumn{1}{l|}{ X-Qual } \\
\hline S-Qual & 4 & 16 & 11 & 31 & $\mathbf{2 4}$ & 2 & 17 & 4 \\
\hline R-Qual & 16 & 14 & 6 & 36 & $\mathbf{3 4}$ & 11 & 15 & 10 \\
\hline P-Value & 11 & 6 & 4 & 18 & $\mathbf{7}$ & 0 & 12 & 2 \\
\hline Loyalty & 31 & 36 & 18 & 30 & $\mathbf{4 8}$ & 10 & 35 & 13 \\
\hline Emotion & 24 & 34 & 7 & 48 & $\mathbf{2 6}$ & 16 & 25 & 15 \\
\hline Empathy & 2 & 11 & 0 & 10 & $\mathbf{1 6}$ & 4 & 9 & 6 \\
\hline Trust & 17 & 15 & 12 & 35 & $\mathbf{2 5}$ & 9 & 10 & 12 \\
\hline X-Qual & 4 & 10 & 2 & 11 & $\mathbf{1 5}$ & 6 & 12 & 0 \\
\hline
\end{tabular}




\section{References}

[1] Nielsen, A Global Consumer Report: Trends in Online Shopping, February 2008, 1-7. [Online] Available: http://at.nielsen.com/site/documents/GlobalOnlineShoppingReportFeb08.pdf

[2] Nielsen, The Digital Media Habits and Attitudes of Southeast Asian Consumer, October 2011, 1-18. [Online] Available: http://at.nielsen.com/site/documents/GlobalOnlineShoppingReportFeb08.pdf

[3] http://en.wikipedia.org/wiki/Singapore

[4] http://nasional.kompas.com/read/2011/09/19/10594911/Jumlah.Penduduk.Indonesia.259.Juta

[5] George, J.F., Influences on the Intent to Make Internet Purchases, Internet Research: Electronic Networking Applications and Policy, 12 (2), 2002, 165-180.

[6] Zeithaml, V.A., A. Parasuraman and Arvind Malhotra, Service Quality Delivery Through Web Sites: A Critical Review of extant Knowledge, Journal of the Academy of Marketing Science, 30 (4), 2002, 362-375.

[7] Rodgers, W., Solomon Negash and Kwanho Suk, The Moderating Effect of On-line Experience on the Antecedents and Consequences of On-Line Satisfaction, Psychology \& Marketing 22 (4), 2005, 313-331.

[8] Yang, H., Assessing the Effects of e-Quality and e-Satisfaction on Website Loyalty, International Journal of Mathematics and Computers in Simulation 1 (3), 2007, 288-294.

[9] Wang, Ming, Assessment of e-Service Quality via e-Satisfaction in e-Commerrce globalization, The Electronic Journal on Information Systems in Developing Countries 11 (10), 2003, 1-4

[10] Li, Hongxiu and Reima Suomi, A Proposed Scale for Measuring E-service Quality, International Journal of u- and e-Service, Science and Technology 2 (1), 2009, 1-10.

[11] Yang, Z. And Xiang Fang. Online Service Quality Dimensions and Their Relationships with Satisfaction: A Content Analysis of Customer Reviews of Securities Brokerage Services, International Journal of Service Industry Management 15 (3), 2004, 302-326.

[12] “Main Segment”, Marketing - Indonesian Magazine, 05 (IX), 2009, 94 - 95.

[13] Tuzovic, S., Frequent (flier) Frustration and the Dark Side of Word-of-Web: Exploring Online Dysfunctional Behavior in Online Feedback Forums, Journal of Services Marketing, 24 (6), 2010, 446-457.

[14] Schweidel, D.A., Wendy W. Moe and Chris Boudreaux, Listening in on Online Conversations: Measuring Brand Sentiment with Social Media, 2011, 1-30. [Online] Available: http://socialmediagovernance.com/downloads/SSRN-id1874892.pdf

[15] Nielsen, Op. Cit., 1-7.

[16] Ashworth, C.J. et al., Web-weaving: An Approach to Sustainable e-Retail and Online Advantage in Lingerie Fashion Marketing, International Jounal of Retail \& Distribution Management, 34 (6), 2006, 497-511.

[17] Mudambi, S.M. and David Schuff, What Makes a Helpful Online Review?: A Study of Customer Reviews on Amazon.Com, MIS Quarterly 34 (1), 2010, 185-200.

[18] Ibid, pp. 185-200.

[19] Ibid, pp. 185-200.

[20] Jourdan, P., Search or Experience Products: An Empirical Investigation of Services, Durable and Non-Durable Goods, Asia Pacific Advances in Consumer Research 4, 2001 167-174.

[21] Mudambi, Op. Cit., pp. 185-200.

[22] Jourdan, Op. Cit., pp. 167-174.

[23] Yoo, C., Jonghee Park and Deborah J. MacInnis, Effects of Store Characteristics and In-Store Emotional Experiences on Store Attitude, Journal of Business Research, 42, 1998. 253-263.

[24] Wilson-Jeanselme, M. and Jonathan Reynolds, Understanding Shoppers' Expectations of Online Grocery Retailing, International Journal of Retail \& Distribution Management 34 (7), 2006, 529-540.

[25] Dholakia, R.R. and Miao Zhao, Effects of Online Store Attributes on Customer Satisfaction and Repurchase Intentions, International Journal of Retail \& Distribution Management 38 (7), 2010, 482-496.

[26] Rajamma, Audhesh K. Paswan and Gopala Ganesh, Services Purchased at Brick and Mortar versus Online Stores, and Shopping Motivation, Journal of Services Marketing, 21 (3), 2007, 200-212.

[27] Khare, A., Ceeba Parveen and Reena Rai, Retailer Behavior as Determinant of Service Quality in Indian Retailing, Journal of Retail and Leisure Property, 9 (4), 2010, 303-317.

[28] Kim, M. and Leslie Stoel, Salesperson Role: Are Online Retailers Meeting Customer Expectation? International Journal of Retail \& distribution Management, 33(4), 2005, 284-297.

[29] Jun, M., Zhilin Yang dan DaeSoo Kim, Customers' Perceptions of Online Retailing Service Quality and their Satisfaction. International Journal of Quality \& Reliability Management 21 (8), 2003, 817-840.

[30] Brengman, M. and Kim Willems, Determinants of Fashion Store Personality: A Consumer Perspective, Journal of Product \& Brand Management, $18(5), 2009,346-355$

[31] Sung, H. and Yangjin Jeon, A Profile of Koreans: Who Purchases Fashion Goods Online? Journal of Fashion Marketing and Management, 13 (1), 2009, 79-97.

[32] Parasuraman, A., Valarie A. Zeithaml and Arvind Malhotra, E-S-QUAL: A Multiple-Item Scale for Assessing Electronic Service Quality, Journal of Service Research 7 (X), 2005, 1-21.

[33] Zeithaml, Op. Cit., 362-365.

[34] Li and Suomi, Op. Cit., 1-10.

[35] Zeithaml et al., Op. Cit., 362-365.

[36] Parasuraman et al., Op. Cit., 1-21.

[37] Swaid, S.I. and Rolf T. Wigand, Key Dimensions of E-commerce Service Quality and Its Relationships to Satisfaction and Loyalty, 20th Bled eConference eMergence: Merging and Emerging Technologies, Processes, and Institutions, Bled, Slovenia, 2007.

[38] Da Silva, R.V. and Sharifah Faridah Syed Alwi, Cognitive, Affective Attributes and Conative, Behavioural Responses in Retail Corporate Branding, Journal of Product \& Brand Management 15 (5), 2006, 293-305.

[39] Chung, Ki-Han and Jae-Ik Shin, The Antecedents and Consequents of Relationship Quality in Internet Shopping, Asia Pacific Journal of Marketing and Logistics 22 (4), 2010, 473-491.

[40] Bartl, M., Steffen Huck and Stephan Ruppert, Netnography Research: Community Insights in the Cosmetic Industry, ESOMAR, Insight Co-Creation, Part 2, 2009, 1-12. [Online] Available: http://ebookbrowse.com-d39459718 
[41] Huang, Y.K. and Wen I. Yang, A study of Internet Book Reviews and Borrowing Intention, Library Review 59 (7), $2010,512-521$.

[42] Adjei, M.T., Stephanie M. Noble and Charles H. Noble, The Influence of C2C Communications in Online Brand Communities on Customer Purchase Behavior, Journal of the Academy of Marketing Science, 38, 2010, 634-653.

[43] Huang and Yang, Op.Cit., 512-521.

[44] Tuzovic, S., Op. Cit., 446-457.

[45] Bartl, Op. Cit., 1-12.

[46] Thomas, J.B. and Cara Okleshen Peters, An Exploratory Investidation of the Virtual Community MySpace.com, Journal of Fashion Marketing and Management 11 (4), 2007, 587-603.

[47] Dellarocas, C, The Digitization of Word of Mouth: Promise and Challenges of Online Feedback Mechanisms, Management Science 49 (10), 2003, 1407-1424.

[48] Bartl, Op. Cit., 1-12.

[49] Hennig - Thurau, T. et al., Electronic Word-of-Mouth Via Consumer-Opinion Platform: What motivates Consumers to Articulate themselves on the Internet? Journal of Interactive Marketing 18 (1), 2004, 38-52.

[50] Langer, R. and Suzanne C. Beckman, Sensitive Research Topics: Netno-graphy Revisited, Qualitative Market Research: An International Journal, $8(2), 2005,189-203$.

[51] Thomas et al., Op.Cit., 587-603.

[52] Zhang, J.Q., Georgiana Craciun and Dongwoo Shin, When does Electronic Word-of-Mouth Matter? A Study of Consumer Product Reviews, Journal of Business Research, 63 (12), 2010, 1336-1341.

[53] Schweidel, Op. Cit., 1-30

[54] Ladhari, R., The Effect of Consumption Emotions on Satisfaction and Word-of-Mouth Communications, Psychology \& Marketing, 24 (12), 2007, 1085-1108.

[55] Ibid, pp. 1085-1108.

[56] Ranaweera, C., and Jaideep Prabhu, On the Relative Importance of Customer Satisfaction and Trust as Determinants of Customer Retention and Positive Word of Mouth, Journal of targeting, Measurement and Analysis for Marketing 12 (1), $2003,82-90$.

[57] Armelini, G. and Villanueva, J., Electronic Word of Mouth: What Do We Know About This Powerful Marketing Tool? e-Business Center Price Water House Coopers \& IESE, 2006, 1-63.

[58] Goyette, Isabelle et al., e-WOM Scale: Word-of-Mouth Measurement Scale for e-Service Context, Canadian Journal of Administrative Sciences 27(5), 2010, 5-23.

[59] Schindler and Bickart, Published Word of Mouth: Referable, Consumer-Generated Information on the Internet, 2004, Chapter Two, 35-61. [Online] Available: http://ebookbrowse.com/schindler-bickart-2005-pdf-d12153249

[60] Huang and Yang, Op.Cit., 512-521.

[61] Xia, L. and Nada Nasr Bechwati, Word of Mouse: The Role of Cognitive Personalization in Online Consumer Reviews, Journal of Interactive Advertising 9 (1), 2008, 3-13.

[62] Ibid, pp. 3-13.

[63] McLean, R. and Nigel M. Blackie, Customer and Company Voices in e-Commerce: A Qualitative Analysis, Qualitative Market Research: An International Journal, 7 (4), 2004, 243-249.

[64] Andreassen, Tor W. and Sandra Streukens, Service Innovation and Electronic Word-of-Mouth: Is it Worth Listening to? Managing Service Quality 19 (3), 2009, 249-265.

[65] Nielsen, Op. Cit, 1-7.

[66] Somprasertsri, G. and Pattarachai Lalitrojwong, Mining Feature-Opinion in Online Customer Reviews for Opinion Summarization, Journal of Universal Computer Science 16 (6), 2010, 938-955.

[67] Chen, Y. and Jinhong Xie, Online Consumer Review: Word-of-Mouth as a New Element of Marketing Communication Mix, Management Science, 54 (3), 2008, 477-491.

[68] Senecal, S. and Jacques Nantel, The Influence of Online Product Recommendations on Consumers' Online Choices, Journal of Retailing, 80, 2004, 159-169.

[69] Lee, Thomas Y., Needs-Based Analysis of Online Customer Reviews, ICEC'07, Minneapolis, Minnesota, USA, 2007.

[70] Chen and Xie, Op. Cit., 477-491 